\title{
Inhibitory effects of compounds from Phyllanthus amarus on nitric oxide production, lymphocyte proliferation, and cytokine release from phagocytes
}

This article was published in the following Dove Press journal:

Drug Design, Development and Therapy

9 June 2016

Number of times this article has been viewed

\author{
Yuandani ${ }^{1,2}$ \\ Ibrahim Jantan' \\ Menaga Ilangkovan' \\ Khairana Husain' \\ Kok Meng Chan ${ }^{3}$ \\ 'Drug and Herbal Research Center, \\ Faculty of Pharmacy, Universiti \\ Kebangsaan Malaysia, Jalan Raja Muda \\ Abdul Aziz, Kuala Lumpur, Malaysia; \\ ${ }^{2}$ Falkultas Farmasi, Universitas \\ Sumatera Utara, USU-Kampus, \\ Medan, Indonesia; ${ }^{3}$ Biomedical \\ Science Programme, Faculty of Health \\ Sciences, Universiti Kebangsaan \\ Malaysia, Jalan Raja Muda Abdul Aziz, \\ Kuala Lumpur, Malaysia
}

Correspondence: Ibrahim Jantan

Drug and Herbal Research Center, Faculty of Pharmacy, Universiti

Kebangsaan Malaysia, Jalan Raja Muda

Abdul Aziz, 50300 Kuala Lumpur,

Malaysia

Tel +60 I 62886445

Fax +60326983271

Email profibj@gmail.com

\begin{abstract}
Standardized extract of Phyllanthus amarus has previously been shown to have a strong inhibitory effect on phagocytic activity of human neutrophils. The current study was carried out to evaluate the effects of constituents of the extract of P. amarus on nitric oxide (NO) production as well as lymphocyte proliferation and cytokine release from phagocytes. Three compounds, ethyl 8-hydroxy-8-methyl-tridecanoate, $7 \beta, 19 \alpha$ dihydroxy-urs-12-ene, and 1,7,8-trihydroxy-2-naphtaldehyde, together with seven known compounds were isolated from the whole plant of $P$. amarus. The isolated compounds and reference standards, ie, gallic acid, ellagic acid, corilagin, and geraniin, which were quantitatively analyzed in the extracts, were evaluated for their effects on immune cells. Among the compounds tested, the lignans, especially phyltetralin and phyllanthin, showed strong inhibition on lymphocyte proliferation with half maximal inhibitory concentration $\left(\mathrm{IC}_{50}\right.$ ) values of $1.07 \mu \mathrm{M}$ and $1.82 \mu \mathrm{M}$, respectively. Ethyl 8-hydroxy-8-methyl-tridecanoate and 1,7,8-trihydroxy-2-naphtaldehyde exhibited strong inhibition on nitric oxide production with $\mathrm{IC}_{50}$ values of $0.91 \mu \mathrm{M}$ and $1.07 \mu \mathrm{M}$, respectively. Of all the compounds, corilagin was the strongest inhibitor of tumor necrosis factor- $\alpha$ release with an $\mathrm{IC}_{50}$ value of $7.39 \mu \mathrm{M}$, whereas geraniin depicted the strongest inhibitory activity on interleukin-1 $\beta$ release with an $\mathrm{IC}_{50}$ value of $16.41 \mu \mathrm{M}$. The compounds constituting the extract of P. amarus were able to inhibit the innate immune response of phagocytes at different steps.
\end{abstract}

Keywords: Phyllanthus amarus (Euphorbiaceae), immunosuppressive effects, 1,7,8-trihydroxy2-naphtaldehyde, $7 \beta, 19 \alpha$-dihydroxy-urs-12-ene, phyllanthin, hypophyllanthin

\section{Introduction}

The immune system is made up of immune cells (neutrophils, monocytes, macrophages, and T-lymphocytes) and specialized immune molecules that are organized to protect the host against foreign invaders such as germs, parasites, and toxins. The immune cells recognize the invading pathogens, leading to the release of several mediators, free radicals, nitric oxide (NO), soluble cytokines, and chemokines, along with the activation of the complement system. ${ }^{1}$ Cellular and humoral immune responses have different roles to play in defending the host. Cellular immunity is mediated by $\mathrm{T}$-cell populations and $\mathrm{CD}^{+}$and $\mathrm{CD}^{+} \mathrm{T}$-cells, while humoral immunity is mediated by antibodies produced by B-cells. Upon activation, $\mathrm{CD}^{+}{ }^{+} \mathrm{T}$-cells differentiate into T-helper (Th) 1 cells and produce cytokines, including IFN- $\gamma$, interleukin (IL)-1 $\beta$, IL-2, IL-6, and tumor necrosis factor (TNF)- $\alpha$, which stimulate delayed-type hypersensitivity and autoimmunity. Th2 cells are characterized by the production of IL-4, IL-5, and IL-10, thereby stimulating humoral immunity. ${ }^{2}$ Besides the defensive roles during infections, the phagocyte--microbe interactions 
when excessively or inappropriately deployed can damage host tissues and contribute to the pathogenesis of various immune and nonimmune chronic inflammatory diseases. Immunomodulators are used to enhance or suppress host defense responses in the treatment of those diseases in which defective immune responses play an important role in determining disease outcomes. These include primary and secondary immunodeficiencies that accompany longstanding infections, as well as debilitating diseases such as cancer, rheumatoid arthritis, and systemic lupus erythematosus, leading to acquired immune deficiencies. ${ }^{3}$

Some therapeutic activities of plant extracts or compounds have been proposed owing to their effects on the immune system. ${ }^{4}$ Previous studies have indicated that many herbs such as Phyllanthus debilis, Trigonella foenum graecum, Pouteria cambodiana, Tinospora cordifolia, Centella asiatica, Panax ginseng, and Picrorhiza scrophulariflora were able to alter the immune function and possess a wide array of immunomodulatory effects. ${ }^{5-7}$ Plant extracts that are capable of interacting with the immune system to upregulate or downregulate specific aspects of the immune system, including both adaptive and innate arms of the immune response, can be potential sources of immunomodulators. The immunological effects of compounds can be assessed based on their selective activities on the different components of the immune system. Search for natural immunomodulators from medicinal plants to substitute conventional therapy has gained momentum in recent years. ${ }^{7,8}$

Phyllanthus amarus Schum. \& Thonn. (Family: Euphorbiaceae) is a herbaceous plant, widely distributed in most tropical and subtropical countries from Africa to Asia, South America, and the West Indies. ${ }^{6}$ It is locally known as "dukung anak" and is highly valued in traditional medicine for its healing properties, to treat inflammatory disorders, viral hepatitis, diarrhea, jaundice, kidney disorders, influenza, diabetes, bronchial infections, sores, swelling, itchiness, and gastric and cardiovascular problems. It is a rich source of phytochemicals, including alkaloids, flavonoids, hydrolyzable tannins, lignans, and polyphenols. ${ }^{9-13}$ The ethnopharmacological uses and studies that reported the usefulness of the extracts of $P$. amarus as anti-inflammatory, antioxidant, antiplasmodial, antimalarial, and antidiabetic have prompted researchers to investigate the possible immunomodulatory effects of its isolated compounds on the cellular immune response. ${ }^{14-19}$ In addition, several lignans isolated from $P$. amarus such as phyltetralin, nirtetralin, and niranthin revealed important in vivo and in vitro antiinflammatory activities. ${ }^{16}$
Our previous studies on the standardized extracts of $P$. amarus and $P$. urinaria have revealed that these extracts exhibited strong immunomodulatory activity on human neutrophils. ${ }^{20}$ High performance liquid chromatography (HPLC) analysis on P. amarus and P. urinaria demonstrated the presence of phyllanthin and hypophyllanthin as well as polar compounds such as gallic acid (GA), ellagic acid (EA), corilagin (Cor), and geraniin (Ger), which significantly inhibited the phagocytic activity of human phagocytes. ${ }^{21}$ In the current study, the effects of compounds constituting the extract of $P$. amarus on various cellular activities, which include NO production of RAW 264.7 cells, T-cell proliferation, and cytokine release by peripheral blood mononuclear cells (PBMCs), were investigated.

\section{Materials and methods Chemicals and reagents}

Dextran from Leuconostoc mesenteroides, phosphatebuffered saline (PBS) tablet, lipopolysaccharide (LPS), 3-(4,5-dimethylthiazol-2-yl)-2,5-diphenyltetrazolium bromide (MTT) reagent, gelatin from bovine skin, type B, ficoll, dimethylsulfoxide (DMSO), Trypan blue were obtained from Fluka Chemicals Ltd. (Gillingham, UK). Lymphoprep was obtained from Fresenius Kabi Norge AS (Halden, Norway). Fetal calf serum (FCS) and penicillin/streptomycin (100×) were obtained from PAA Laboratories (North Dartmouth, MA, USA). GA, EA, Cor, and Ger (all standards $>98 \%$ purity) were purchased from ChromaDex Inc (Irvine, CA, USA). $N$-1(1-Naphthylethylenediamine dihydrochloride was purchased from SigmaAldrich Co. (St Louis, MO, USA). [ $\left.{ }^{3} \mathrm{H}\right]$ Thymidine and liquid scintillation cocktail solutions, Ultima Gold, were purchased from PerkinElmer Inc. (Waltham, MA, USA). Dulbecco's Modified Eagle's Medium (DMEM) was obtained from Thermo Fisher Scientific (Waltham, MA, USA). RAW 264.7 cells were purchased from American Type Culture Collection (ATCC, Manassas, VA, USA). Sulfanilamide was obtained from MP Biomedicals (Illkirch Cedex, France). Enzyme-linked immunosorbent assay (ELISA) kits were obtained from Cayman (Ann Arbor, MI, USA). Dexamethasone (99.0\% purity) and prednisolone ( $99 \%$ purity) were obtained from Duopharma (Klang, Malaysia). $\mathrm{A} \mathrm{CO}_{2}$ incubator (Shel Lab, Cornelius, OR, USA), light microscope, microplate reader (Thermo Fisher Scientific), and liquid scintillation analysis (PerkinElmer Inc.) were also used in this assay. Molecular weights of the compounds were recorded by ESIMS (electrospray ionization mass spectrometer) using electrospray ionization time-of-flight mass spectrometry (MS; Bruker MicroToF-Q 86; Bruker BioSpin AG, Fällanden, Switzerland) and gas chromatography-MS 
(Agilent 7890A; Agilent Technologies, Santa Clara, CA, USA). The ${ }^{1} \mathrm{H}$ and ${ }^{13} \mathrm{C}$ nuclear magnetic resonance (NMR) spectra were carried out on a Varian VNMRS $500 \mathrm{MHz}$ with tetramethylsilane as internal standard.

\section{Cell culture}

RAW 264.7 cells, a murine macrophage cell line, were grown in DMEM supplemented with $10 \%$ of FCS, $1 \%$ of penicillin (100 units $/ \mathrm{mL})$, and streptomycin $(100 \mu \mathrm{g} / \mathrm{mL})$. They were maintained at $37^{\circ} \mathrm{C}$ in a humidified atmosphere of $5 \% \mathrm{CO}_{2} \cdot{ }^{22}$

\section{Plant collection}

The whole plants of P. amarus (UKMB 30075) were collected from Marang, Kuala Terengganu, Malaysia, in June 2012. The plant was identified by Doctor Abdul Latif Mohamad of Faculty of Science and Technology, Universiti Kebangsaan Malaysia (UKM), and deposited at the Herbarium of UKM, Bangi, Malaysia.

\section{Extraction and isolation of compounds}

The dried material (667 g) was ground and macerated, and then subjected to sequential extraction method with $n$-hexane, ethyl acetate (EtOAc), and methanol $(\mathrm{MeOH})$ $(3 \times 1,500 \mathrm{~mL})$. The solvents were removed under reduced pressure to obtain extracts of $P$. amarus ( $n$-hexane extract, 17.2 g, 2.58\% w/w; EtOAc extract, 29.8 g, 4.46\% w/w; $\mathrm{MeOH}$ extract, $54.2 \mathrm{~g}, 8.12 \% \mathrm{w} / \mathrm{w})$. Ten grams of $n$-hexane extract was subjected to column chromatography $(\mathrm{CC} ; 5 \mathrm{~cm}$ of diameter) on silica gel $(40-63 \mu \mathrm{m})$ and eluted $(100 \mathrm{~mL}$ for each elution) with a gradient system of $n$-hexane-EtOAc (10:0 to $0: 10, \mathrm{v} / \mathrm{v})$ and EtOAc-MeOH (10:0 to 0:10, v/v) to yield $20 \mathrm{~mL}$ of each fraction. Each fraction was checked by thin-layer chromatography, and fractions with same spots were combined to afford 19 fractions (F1-F19). Fraction F1 $(1.781 \mathrm{~g})$ was subjected to silica gel $\mathrm{CC}$ and eluted with a $n$-hexane-EtOAc gradient to afford fractions F1A-E. Fractions $1 \mathrm{~A}$ and $1 \mathrm{~B}$ were further purified by silica $\mathrm{CC}$ and eluted with $n$-hexane-EtOAc (9:1 to 8:2) to yield $\mathbf{1}(8.2 \mathrm{mg})$ and 6 (2.5 mg). Fraction F2 (703.5 mg) was chromatographed on silica CC repeatedly with $n$-hexane-EtOAc (8:2) and purified by recrystallization from $n$-hexane to afford $\mathbf{3}(235.8 \mathrm{mg})$. Fractions F10 (664 mg), F14 (949 mg), and F15 (579 mg) were treated in a similar way to obtain a mixture of $\mathbf{4}$ and $\mathbf{5}$ (47.4 mg), 2 (4.1 mg), and 7 (269 mg), respectively. Further purification of fractions F16 and F18 by silica CC eluted with $n$-hexane-EtOAc (6:4) afforded $8(10.1 \mathrm{mg})$ and 9 (115.0 mg), respectively. Ten grams of EtOAc extract was fractionated by vacuum liquid chromatography on silica gel type $60 \mathrm{H} \mathrm{F}_{254}(10-40 \mu \mathrm{m})$ and eluted with a gradient system of $n$-hexane:EtOAc (10:0 to 0:10, v/v) and EtOAc:MeOH (10:0 to $0: 10, \mathrm{v} / \mathrm{v})$ to afford 12 fractions. Repeated silica gel column of fractions FE4 $(1.1 \mathrm{~g})$ and FE6 (0.222 g) with a gradient system of $n$-hexane:EtOAc (10:0 to $0: 10, \mathrm{v} / \mathrm{v})$ and EtOAc:MeOH (10:0 to 0:10, v/v) afforded 10 (5.9 mg). Fifteen grams of $\mathrm{MeOH}$ extract was treated similarly as the EtOAc extract to yield $\mathbf{1 0}(2 \mathrm{mg})$. The structures of the known compounds were determined by a combination of ESIMS, ${ }^{1} \mathrm{H}$, and ${ }^{13} \mathrm{C}$ NMR techniques, and by comparison of their spectral data with literature values. The purities of all isolated compounds were $>98 \%$ based on their physicochemical properties, HPLC, NMR, and MS-time-of-flight data.

Ethyl 8-hydroxy-8-methyl-tridecanoate (1): White solid, $R_{\mathrm{f}} 0.6$ in $n$-hexane-EtOAc $(8: 2) ; \mathrm{mp} 69^{\circ} \mathrm{C}-71^{\circ} \mathrm{C}$, ultraviolet (UV) $\left(\mathrm{CHCl}_{3}\right) \lambda_{\text {max }}$ : weak absorption in $242 \mathrm{~nm}$; infrared (IR) $v_{\max }(\mathrm{KBr}): 3,436(\mathrm{OH}), 1,736(\mathrm{C}=\mathrm{O}) \mathrm{cm}^{-1}$; gas chromatography-MS: $\mathrm{C}_{16} \mathrm{H}_{32} \mathrm{O}_{3},[\mathrm{M}]^{+} 272 .{ }^{1} \mathrm{H}$ NMR $\left(\mathrm{CDCl}_{3}\right) \delta 0.87$ ( $m, \mathrm{H}-1, \mathrm{H}-42, \mathrm{H}-43$ ), 1.26 (bs), 1.62 (dd, H-2, H-4, J=14, $7.0 \mathrm{~Hz}$ ), 2.29 ( $t, \mathrm{H}-37, J=8.0 \mathrm{~Hz}), 4.06(t, \mathrm{H}-39, J=7.0 \mathrm{~Hz})$ ppm and ${ }^{13} \mathrm{C}$ NMR $\left(\mathrm{CDCl}_{3}\right) . \delta 14.1,22.7,25.1,25.9,28.7$, 29.2, 29.3, 29.4, 29.5, 29.6, 29.7, 31.9, 34.4, 64.4, 174.0. ${ }^{1} \mathrm{H}$ and ${ }^{13} \mathrm{C}$ spectra of compound $\mathbf{1}$ are shown in Figures S1 and $\underline{\mathrm{S} 2}$, respectively.

$7 \beta, 19 \alpha$ Dihydroxy-urs-12-ene (6): White needle-like crystals, $R_{\mathrm{f}} 0.6$ in $n$-hexane-EtOAc $(8: 2) ; \mathrm{mp} 59^{\circ} \mathrm{C}-60^{\circ} \mathrm{C}$, $\mathrm{UV}(\mathrm{MeOH}) \lambda_{\text {max }}: 251 \mathrm{~nm}$; IR $v_{\max }(\mathrm{KBr}): 3,504(\mathrm{OH}), 1,650$ $(\mathrm{C}=\mathrm{C}) \mathrm{cm}^{-1}$; HRESIMS (high resolution electrospray ionization mass spectrometry; positive ion mode): $\mathrm{m} / \mathrm{z} 442.2888$ $[\mathrm{M}]^{+}, 465.3560[\mathrm{M}+\mathrm{Na}]^{+}\left(\right.$Calcd for $\mathrm{C}_{30} \mathrm{H}_{52} \mathrm{O}_{2}, \mathrm{C}_{30} \mathrm{H}_{52} \mathrm{O}_{2}+\mathrm{Na}$, 442.38, 465.3698, respectively); for ${ }^{1} \mathrm{H}$ NMR and ${ }^{13} \mathrm{C} \mathrm{NMR}$ spectroscopic data (Table 1). ${ }^{1} \mathrm{H}$ and ${ }^{13} \mathrm{C}$ spectra of compound $\mathbf{6}$ are shown in Figures S3 and $\underline{\mathrm{S} 4}$, respectively.

1,7,8-Trihydroxy-2-naphtaldehyde (10): White brown semi-solid, UV (MeOH) $\lambda_{\text {max }}: 283.50 \mathrm{~nm}$ and $221 \mathrm{~nm}$; HRESIMS (positive ion mode): $\mathrm{m} / z$ 205.0854 $[\mathrm{M}+\mathrm{H}]^{+}(\mathrm{Calcd}$ for $\left.\mathrm{C}_{11} \mathrm{H}_{8} \mathrm{O}_{4}+\mathrm{H}, 204.0423\right)$; for ${ }^{1} \mathrm{H}$ NMR and ${ }^{13} \mathrm{C}$ NMR spectroscopic data (Table 2). ${ }^{1} \mathrm{H}$ and ${ }^{13} \mathrm{C}$ spectra of compound $\mathbf{1 0}$ are shown in Figures S5 and S6, respectively.

\section{Quantitative determination of the major components of $80 \%$ ethanol extract of P. amarus by HPLC}

The diluted solutions of $80 \%$ ethanol extract and the reference standards (GA, EA, Cor, Ger) were analyzed separately by using a validated reversed-phase HPLC method as described earlier by Jantan et al. ${ }^{21}$ 
Table I NMR spectroscopic data $\left(500 \mathrm{MHz} \mathrm{CDCl}_{3}\right)$ for compound 6 ( $\delta$ in ppm)

\begin{tabular}{|c|c|c|c|c|c|}
\hline Position & $\delta_{\mathrm{c}}$ & $\begin{array}{l}\delta_{\mathrm{H}}, \text { multiplicity } \\
(\mathrm{i} \text { in } \mathrm{Hz})\end{array}$ & HSQC & НМВС & NOESY \\
\hline \multirow[t]{2}{*}{1} & 34.1 & $\mathrm{I} .42, \mathrm{~m}$ & $\mathrm{C}-\mathrm{I}, \mathrm{H}-\mathrm{I}$ & C-II & - \\
\hline & & $\mathrm{I} .45, \mathrm{~m}$ & & C-II & \\
\hline \multirow[t]{2}{*}{2} & 18.1 & I.39, m & $\mathrm{C}-2, \mathrm{H}-2$ & C-5 & - \\
\hline & & $\mathrm{I} .52, \mathrm{~m}$ & & C-5 & \\
\hline \multirow[t]{2}{*}{3} & 28.9 & $1.14, \mathrm{~m}$ & $\mathrm{C}-3, \mathrm{H}-3$ & - & - \\
\hline & & $1.35, \mathrm{~m}$ & & - & \\
\hline \multirow[t]{2}{*}{4} & 27.8 & I.60, m & $\mathrm{C}-4, \mathrm{H}-4$ & - & - \\
\hline & & $\mathrm{I} .67, \mathrm{~m}$ & & - & \\
\hline 5 & 51.7 & $1.58, \mathrm{~m}$ & $\mathrm{C}-5, \mathrm{H}-5$ & - & - \\
\hline \multirow[t]{2}{*}{6} & 28.3 & I.77, m & $\mathrm{C}-6, \mathrm{H}-6$ & - & - \\
\hline & & $\mathrm{I} .83, \mathrm{~m}$ & & - & \\
\hline 7 & 76.4 & $3.45, \mathrm{~m}$ & C-7, H-7 & - & $\mathrm{H}-24,6$ \\
\hline 8 & 42.8 & - & & - & - \\
\hline 9 & 40.8 & - & & - & - \\
\hline 10 & 38.6 & - & & - & - \\
\hline \multirow[t]{2}{*}{ II } & 24.0 & $\mathrm{I} .8 \mathrm{I}, \mathrm{m}$ & C-II, H-II & - & $\mathrm{H}-2 \mathrm{I}$ \\
\hline & & $\mathrm{I} .91, \mathrm{~m}$ & & - & \\
\hline 12 & 122 & $5.58, d(5.5)$ & $\mathrm{C}-12, \mathrm{H}-12$ & C- $18,17,11,9$ & $\mathrm{H}-26,24,6$ \\
\hline 13 & 141.9 & - & & - & - \\
\hline 14 & 39.3 & - & & - & - \\
\hline \multirow[t]{2}{*}{15} & 19.9 & $0.83, \mathrm{~m}$ & $\mathrm{C}-15, \mathrm{H}-15$ & - & - \\
\hline & & $1.18, \mathrm{~m}$ & & - & \\
\hline 16 & 35.4 & $1.56, \mathrm{~m}$ & $\mathrm{C}-16, \mathrm{H}-16$ & C-22, 19, 15, 8 & - \\
\hline 17 & 44.3 & $\mathrm{I} .46, \mathrm{~m}$ & $\mathrm{C}-17, \mathrm{H}-17$ & - & $\mathrm{H}-25,2 \mathrm{I}$ \\
\hline 18 & 50.2 & $2.05, d(15)$ & $\mathrm{C}-18, \mathrm{H}-18$ & - & - \\
\hline 19 & 60.0 & $0.97(s)$ & $\mathrm{C}-19, \mathrm{H}-19$ & - & - \\
\hline 20 & 30.8 & 1.32 & $\mathrm{C}-20, \mathrm{H}-20$ & - & - \\
\hline \multirow[t]{2}{*}{21} & 29.1 & $1.06, \mathrm{~m}$ & $\mathrm{C}-2 \mathrm{I}, \mathrm{H}-2 \mathrm{I}$ & - & $\mathrm{H}-30,17$ \\
\hline & & $1.18, \mathrm{~m}$ & & - & \\
\hline 22 & 34.8 & - & & - & - \\
\hline 23 & 14.9 & $0.89, \mathrm{~s}$ & $\mathrm{C}-23, \mathrm{H}-23$ & C- 10,5 & $\mathrm{H}-25$ \\
\hline 24 & 25.5 & I.II, s & $\mathrm{C}-24, \mathrm{H}-24$ & $C-26,13,9,7$ & - \\
\hline 25 & 16.1 & $0.75, \mathrm{~s}$ & $\mathrm{C}-25, \mathrm{H}-25$ & $C-16,10,8$ & - \\
\hline 26 & 29.4 & $\mathrm{I} .0 \mathrm{I}, \mathrm{s}$ & $\mathrm{C}-26, \mathrm{H}-26$ & $C-24,13,9,7$ & - \\
\hline 27 & 15.7 & $0.97, \mathrm{~s}$ & $\mathrm{C}-27, \mathrm{H}-27$ & C-22, 21, 17 & $\mathrm{H}-28, \mathrm{I} 6$ \\
\hline 28 & 22.9 & $0.79, \mathrm{~d}(6.5)$ & $\mathrm{C}-28, \mathrm{H}-28$ & C- $29,20,19$ & - \\
\hline 29 & 21.9 & $0.85, \mathrm{~s}$ & C-29, H-29 & $C-28,20,19$ & - \\
\hline 30 & 17.9 & $0.86, \mathrm{~s}$ & $\mathrm{C}-30, \mathrm{H}-30$ & C- 18,17 & $C-21,16$ \\
\hline
\end{tabular}

Note: - indicates data not applicable.

Abbreviations: HMBC, heteronuclear multiple bond correlation; HSQC, heteronuclear single-quantum correlation; NMR, nuclear magnetic resonance; NOESY, nuclear Overhauser effect spectroscopy; s, singlet; d, doublet; m, multiplet.

Table 2 NMR spectroscopic data $(500 \mathrm{MHz}, \mathrm{MeOD})$ for compound 10 ( $\delta$ in Ppm)

\begin{tabular}{|c|c|c|c|c|}
\hline Position & $\delta_{\mathrm{c}}$ & $\delta_{\mathrm{H}}(J$ in $\mathrm{Hz})$ & HMBC & NOESY \\
\hline 1 & 164.1 & - & - & - \\
\hline 2 & | 28.7 & - & - & - \\
\hline 3 & 132.1 & $7.78, d(8.5)$ & C-I, 4, II & $\mathrm{H}-4,5$ \\
\hline 4 & 115.6 & $6.92, \mathrm{~d}(9.0)$ & C-2 & $\mathrm{H}-3,6$ \\
\hline 5 & 115.6 & $6.92, \mathrm{~d}(9.0)$ & C-7 & - \\
\hline 6 & 132.1 & $7.78, d(8.5)$ & C-8 & - \\
\hline 7 & 127.6 & - & - & - \\
\hline 8 & 164.1 & - & - & - \\
\hline 9 & 114.4 & - & - & - \\
\hline 10 & 103.4 & - & - & - \\
\hline 11 & 191.4 & $9.76, \mathrm{~s}$ & C- 2,3 & $\mathrm{H}-3$ \\
\hline
\end{tabular}

Note: - indicates data not applicable.

Abbreviations: $\mathrm{HMBC}$, heteronuclear multiple bond correlation; NMR, nuclear magnetic resonance; NOESY, nuclear Overhauser effect spectroscopy.

\section{Isolation of PBMCs}

PBMCs were isolated by using a modified method of GmeligMeyling and Waldmann. ${ }^{23}$ Briefly, venous blood $(10 \mathrm{~mL})$ was obtained in heparin-containing tubes containing equal amount of physiological saline (1:1) by aseptic vein puncture from healthy human volunteers who were nonsmokers, had fasted overnight, and did not take any medicine or supplements. Written informed consent was provided for protection of the rights and welfare of human subjects involved in this research. The diluted blood was then centrifuged at $400 \times g$ for 20 minutes after carefully layered on lymphoprep. The monocytes, formed as a distinct band at the medium interface, were collected carefully using a Pasteur pipette. The collected 
cells were diluted with PBS and centrifuged at $250 \times g$ for 10 minutes for the purification of cells. The cells were then suspended in PBS and counted using a hemocytometer. The number of cells was adjusted to $5 \times 10^{5}$ cells $/ \mathrm{mL}$. The use of human blood was approved by the Human Ethical Committee of UKM (approval number: FF/2012/Ibrahim/23-May/432May 2012-August 2013).

\section{Cell viability}

Cytotoxicity of samples and positive controls (dexamethasone and prednisolone) on PBMC and RAW 264.7 cells was determined using MTT test as previously described by Jantan et al. ${ }^{21}$ One hundred microliters of RAW 264.7 cells $\left(1 \times 10^{6} / \mathrm{mL}\right)$ or PBMC $\left(5 \times 10^{5} / \mathrm{mL}\right)$ suspensions in RPMI 1640 supplemented with $10 \%$ of FCS were incubated with $100 \mu \mathrm{L}$ samples of five different concentrations $(3.125-100 \mu \mathrm{g} / \mathrm{mL})$ in a 96 -well round bottom microplate at $37^{\circ} \mathrm{C}, 5 \% \mathrm{CO}_{2}$, for 2 days and 4 days, respectively. Plates were incubated again for 4 hours at $37^{\circ} \mathrm{C}, 5 \% \mathrm{CO}_{2}$, with $25 \mu \mathrm{L}$ of MTT reagent $(1 \mathrm{mg} / \mathrm{mL})$. Supernatant was discarded, the formazan produced in each well was dissolved in DMSO, and the optical densities were measured by ELISA readers at $570 \mathrm{~nm}$.

\section{NO production}

The NO assay was performed as described earlier with slight modification. ${ }^{24}$ Briefly, RAW 264.7 cells $\left(1 \times 10^{6}\right.$ cells $\left./ \mathrm{mL}\right)$ were incubated with different concentrations of compounds ranging from $3.125 \mu \mathrm{g} / \mathrm{mL}$ to $50 \mu \mathrm{g} / \mathrm{mL}$ or dexamethasone as positive control $(0.0004-4 \mu \mathrm{g} / \mathrm{mL})$ followed by stimulation with LPS $(1 \mu \mathrm{g} / \mathrm{mL})$. The compounds or the positive control were dissolved in DMSO and diluted with DMEM into the appropriate concentrations. The final concentration of DMSO was adjusted to $0.1 \%(\mathrm{v} / \mathrm{v})$ to eliminate the effect of the solvent on cytotoxicity and NO production. The control wells contained the same amount of DMSO but no compounds. The plates were incubated for 24 hours at $37^{\circ} \mathrm{C}, 5 \% \mathrm{CO}_{2}$. Amounts of nitrite were measured using Griess reagent (1\% sulfanilamide and $0.1 \%$ naphthylethylenediamine dihydrochloride in $2.5 \%$ phosphoric acid). Then, $100 \mu \mathrm{L}$ of culture supernatant was added to $100 \mu \mathrm{L}$ of Griess reagent, followed by incubation for 10 minutes in the dark. Absorbance was measured at $550 \mathrm{~nm}$ in a microplate reader. Nitrite concentrations were calculated using standard solutions of $\mathrm{NaNO}_{3}$.

\section{Lymphocyte proliferation}

The antiproliferation effect of compounds was determined by measuring the inhibition of phytohemagglutinin (PHA)-induced T-cell proliferation by incorporation of radioactive thymidine following a methodology reported by Amirghofran et al. ${ }^{25}$ Briefly, $50 \mu \mathrm{L}$ of mononuclear cells suspension was added to each well of 96-well plates containing $50 \mu \mathrm{L}$ RPMI 1640 medium supplemented with $10 \%$ of FCS, $1 \%$ of penicillin (100 units $/ \mathrm{mL})$, and streptomycin $(100 \mu \mathrm{g} / \mathrm{mL})$. Then, $50 \mu \mathrm{L}$ of different concentrations of the compounds ranging from $3.125 \mu \mathrm{g} / \mathrm{mL}$ to $50 \mu \mathrm{g} / \mathrm{mL}$ or prednisolone $(0.0005-5 \mu \mathrm{g} / \mathrm{mL})$ and $50 \mu \mathrm{L}$ of media containing PHA $(20 \mu \mathrm{g} / \mathrm{mL})$ were added to the mixture. The compounds and prednisolone were dissolved in DMSO and adjusted to the appropriate concentrations by the cell culture medium. The final concentration of DMSO at the cells was $0.1 \%$. At this concentration, DMSO did not show any effects on the lymphocyte proliferation. The plates were incubated in a $\mathrm{CO}_{2}$ incubator for 3 days. The amount of $25 \mu \mathrm{L}$ of $\left[{ }^{3} \mathrm{H}\right]$ thymidine $(0.5 \mu \mathrm{Ci} /$ well $)$ was then added to the wells and incubated again for 18 hours. The cells were harvested using a cell harvester. Harvested cells were dissolved in $2.5 \mathrm{~mL}$ of liquid scintillation cocktail. Then, $\left[{ }^{3} \mathrm{H}\right]$ thymidine incorporation was measured as count per minute using liquid scintillation analysis.

\section{Cytokine release assay}

The effect of the bioactive isolates on the synthesis of inflammatory cytokines, TNF- $\alpha$, and IL-1 $\beta$ in mononuclear cells was measured by ELISA. LPS $(1 \mu \mathrm{g} / \mathrm{mL})$ and isolated compounds (3.125-100 $\mu \mathrm{g} / \mathrm{mL})$ or dexamethasone $(0.0005-5 \mu \mathrm{g} / \mathrm{mL})$ were incubated with PBMC suspension for 12 hours at $37^{\circ} \mathrm{C}, 5 \%$ $\mathrm{CO}_{2}$. The compounds and standards were dissolved in DMSO and diluted in cell culture medium to the required concentrations. Then, they were centrifuged at $300 \times g$ for 10 minutes at $4{ }^{\circ} \mathrm{C}$, and the supernatant was transferred to 96 -well plates. The assessment of cytokine levels in the supernatant of human blood cell cultures was accomplished using the appropriate ELISA kit. The cytokine concentration in the sample was determined from appropriate calibration curves. ${ }^{26}$

\section{Statistical analysis}

All the data were analyzed using Statistical Package for Social Sciences Version 15.0. Each sample was measured in triplicate, and the data were presented as mean \pm standard error of the mean. The half maximal inhibitory concentration $\left(\mathrm{IC}_{50}\right)$ values were calculated using Graph Pad Prism 6 software. The values were obtained from at least three determinations. Data were analyzed using a one-way ANOVA for multiple comparisons. $P \leq 0.05$ was considered to be different significantly.

\section{Results and discussion}

The whole plants of $P$. amarus were sequentially extracted with $n$-hexane, EtOAc, and $\mathrm{MeOH}$. The $n$-hexane extract 
was subjected to repeated silica $\mathrm{CC}$ to yield two new compounds, ethyl 8-hydroxy-8-methyl-tridecanoate (1) and $7 \beta, 19 \alpha$ dihydroxy-urs-12-ene (6), in addition to the known compounds, isolintetralin (2), 1-triacontanol (3), stigmasterol (4), $\beta$-sitosterol (5), hypophyllanthin (7), phyltetraline (8), and phyllanthin (9). Fractionation of the EtOAc extract by vacuum liquid chromatography on silica gel type $60 \mathrm{H}$, followed by successive separations on silica $\mathrm{CC}$, afforded a new compound, 1,7,8-trihydroxy-2-naphtaldehyde (10). The $\mathrm{MeOH}$ extract was treated similarly as the EtOAc extract and afforded compound 10. The structures of the new compounds are shown in Figure 1. The structures of the known compounds were elucidated by a combination of ESIMS, ${ }^{1} \mathrm{H}$, and ${ }^{13} \mathrm{C}$ NMR techniques, and by comparison of their spectral data with literature values. ${ }^{27-29}$

Analysis of the NMR spectrum of compound 1 showed the presence of a long-chain hydrocarbon, and one carbon was attributed to a carbonyl group. The ${ }^{1} \mathrm{H}$ NMR of 1 showed a singlet at $\delta_{\mathrm{H}} 0.87$ for three methyl groups, a multiplet at $\delta_{\mathrm{H}} 1.61$ for four $-\mathrm{CH}_{2}$ protons next to a $\mathrm{CHOH}$ group, and a triplet at $\delta_{\mathrm{H}} 2.29$ for two protons of $\mathrm{CH}_{2}$ adjacent to a $\mathrm{C}=\mathrm{O}$ group, while two protons at $\delta_{\mathrm{H}} 4.05$ were assigned to $\mathrm{CH}_{2}$ attached to $\mathrm{CH}_{2} \mathrm{OCO}$. The remaining methylene appeared as a broad singlet at $\delta_{\mathrm{H}} 1.26$. The ${ }^{13} \mathrm{C}$ NMR spectrum of 1 exhibited signals for carbonyl carbon at $\delta_{\mathrm{C}} 174.03$ and hydroxymethylene carbon at $\delta_{\mathrm{C}} 64.41$. The mass spectrum of 1 exhibited a molecular ion peak with undetectable two ion radicals at $m / z 270$ corresponding to a molecular formula of an ethyl ester, $\mathrm{C}_{16} \mathrm{H}_{32} \mathrm{O}_{3},[\mathrm{M}]^{+} 272$. The ion fragments arising at $m / z 74\left(73+1\left[\mathrm{CH}_{3} \mathrm{CH}_{2} \mathrm{COO}\right]^{+}\right), 87\left[\mathrm{CH}_{2}\right]^{+}, 143\left[\left(\mathrm{CH}_{2}\right)_{4}\right]$, and $155\left[\mathrm{CH}_{2}\right]$ were due to two undetectable radicals. The loss of 44 ions demonstrated the fragment ion of methylhydroxy branched $\left[\mathrm{COHCH}_{3}\right]^{+}$, whereas the loss of 71 ions demonstrated the fragment ion of $\left[\left(\mathrm{CH}_{2}\right)_{4} \mathrm{CH}_{3}\right]^{+}$. Based on the data, we concluded that $\mathbf{1}$ was a new ethyl ester, namely ethyl 8-hydroxy-8-methyl-tridecanoate. The long-chain ethyl esters have been previously identified in several essential oils. For example, ethyl tridecanoate was identified in the essential oils from two species of Houttuynia. ${ }^{30}$

Compound 6 was obtained as white needle-like crystals and has a molecular formula of $\mathrm{C}_{30} \mathrm{H}_{52} \mathrm{O}_{2}$ as determined by HRESIMS $\left(m / z 442.2888[\mathrm{M}]^{+}, 465.3560[\mathrm{M}+\mathrm{Na}]^{+}\right) .{ }^{13} \mathrm{C}$ NMR exhibited 30 signals in accordance with the molecular formula $\mathrm{C}_{30} \mathrm{H}_{50} \mathrm{O}_{2} .{ }^{1} \mathrm{H}-\mathrm{NMR}$ (Table 1) showed eight methyls at $\delta_{\mathrm{H}} 0.75,0.79,0.85,0.86,0.89,0.97,1.01$, and 1.11 . All these peaks appeared as singlets except one methyl at

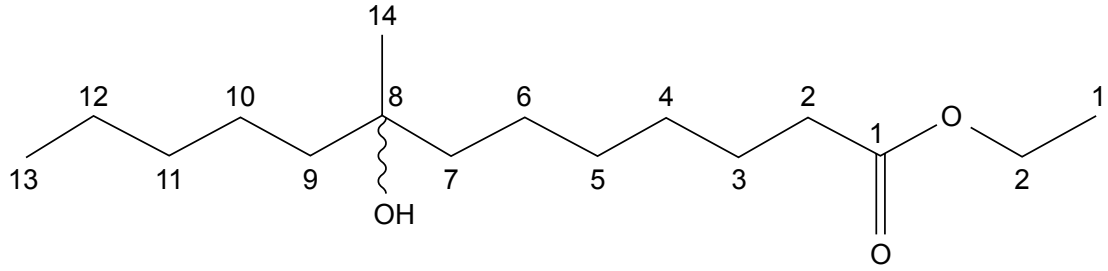

(1)

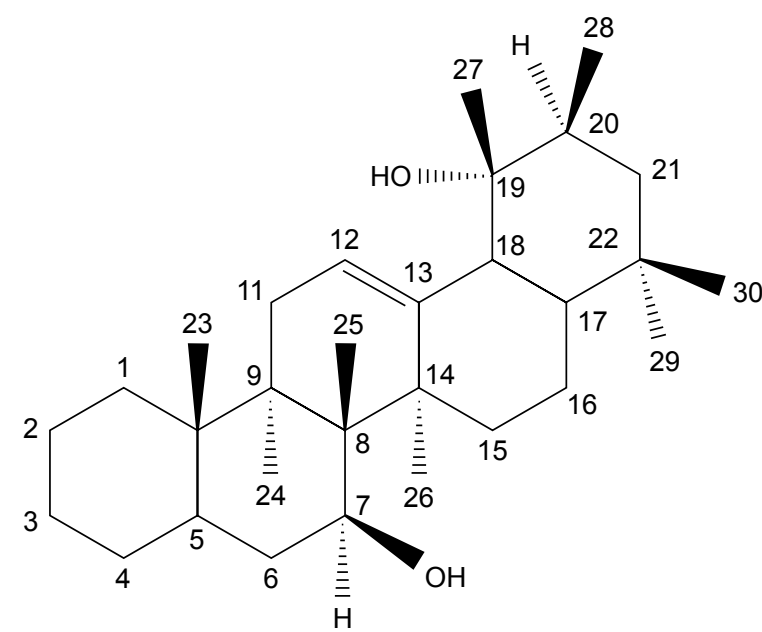

(6)

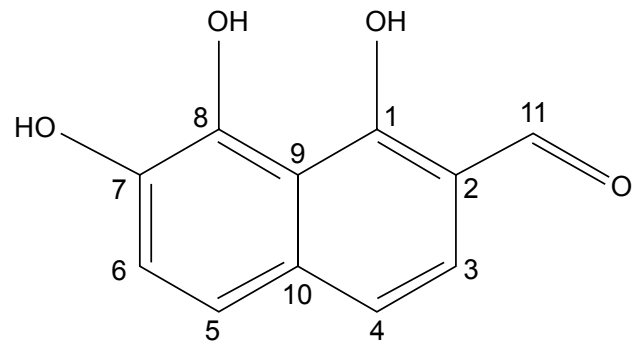

(10)

Figure I Structures of new compounds isolated from $P$. amarus. Abbreviation: P. amarus, Phyllanthus amarus. 
$\delta_{\mathrm{H}} 0.79$ as doublet. A signal at $\delta_{\mathrm{H}} 3.45(\mathrm{H}-7)$ was attributable to a proton which was carried by a carbon bonded to a hydroxyl group. In the spectrum, there was also present an olefinic proton at $\delta_{\mathrm{H}} 5.58$. In the heteronuclear multiple bond correlation (HMBC) spectrum, the protons resonating at $\delta_{\mathrm{H}} 0.79(\mathrm{H}-28)$ showed ${ }^{3} J$ correlation with $\mathrm{C}-19\left(\delta_{\mathrm{C}} 60.1\right)$ and ${ }^{2} J$ coupling with $\mathrm{C}-20\left(\delta_{\mathrm{C}} 30.8\right)$. The methyl at C-25 was observed to correlate with C-8 $\left(\delta_{\mathrm{C}} 42.8\right)\left({ }^{2} J\right)$ and C-10 $\left(\delta_{\mathrm{C}} 51.7\right)\left({ }^{3} J\right)$, whereas the methyl protons at $\mathrm{C}-26\left(\delta_{\mathrm{C}} 1.01\right)$ showed ${ }^{3} J$ correlation with C-13 $\left(\delta_{\mathrm{C}} 141.9\right)$ and C-7 $\left(\delta_{\mathrm{C}} 76.4\right)$. The relative configuration of 6 was determined using nuclear Overhauser effect spectroscopy (NOESY) correlation and was supported by comparison with literature values for similar compounds. The correlations between $\mathrm{H}-7$ and $\mathrm{H}-24, \mathrm{H}-6$, as well as between $\mathrm{H}-12$ and $\mathrm{H}-26, \mathrm{H}-24, \mathrm{H}-6$ implied that these protons accepted $\alpha$-orientation. The $\mathrm{OH}$ position at $\mathrm{C}-7$ has been assigned by $\mathrm{HMBC}$ analysis and supported by NOESY correlations. In the HMBC spectrum, the protons resonating at $\delta_{\mathrm{H}} 1.11(\mathrm{H}-24)$ showed ${ }^{3} J$ correlation with $\delta_{\mathrm{C}} 76.4(\mathrm{C}-7)$ and $\delta_{\mathrm{H}} 1.01(\mathrm{H}-26)$ showed ${ }^{3} J$ correlation with $\delta_{\mathrm{C}} 76.4(\mathrm{C}-7)$. Meanwhile, $\delta_{\mathrm{H}} 1.01(\mathrm{H}-26)$ also showed ${ }^{3} J$ correlation with $\delta_{\mathrm{C}} 141.9(\mathrm{C}-13)$ and $\delta_{\mathrm{C}} 40.8(\mathrm{C}-9)$. NOESY correlations displayed the correlations between $\mathrm{H}-7$ and $\mathrm{H}-24, \mathrm{H}-6$, as well as between $\mathrm{H}-12$ and H-26, H-24, H-6. The $7_{\beta}$-hydroxyl position was indicated by NOESY from the $\mathrm{H}-7{ }_{\alpha}$. The relative configuration of the hydroxyl at C-19 was deduced to be $\alpha$ by NOESY correlations at the $\mathrm{H}-27_{\beta}$ position which correlated with C-19 with H-28, H-16. Heteronuclear single-quantum correlation (HSQC) and HMBC spectra of compound $\mathbf{6}$ are shown in Figures S7 and S8, respectively. Figure 2 shows HMBC and NOESY correlations, respectively, of compound $\mathbf{6}$. The complete data of NOESY, HSQC, and HMBC experiments are shown in Table 1. Based on these data, we concluded that compound $\mathbf{6}$ was a new pentacyclic triterpene, $7 \beta, 19 \alpha$ dihydroxy-urs-12-ene.

Compound 10 was obtained as a white brown semisolid. The HRESIMS spectrum exhibited a molecular ion peak $[\mathrm{M}+\mathrm{H}]^{+}$, at $\mathrm{m} / z 205.0854$ suggesting a molecular formula of $\mathrm{C}_{11} \mathrm{H}_{8} \mathrm{O}_{4}$. The ${ }^{1} \mathrm{H}$ and ${ }^{13} \mathrm{C}$ NMR spectra of $\mathbf{1 0}$ indicated that it was a naphthalene derivative. The ${ }^{1} \mathrm{H}$ spectrum showed three proton peaks: two doublets for two protons and one doublet for one proton. There were three protons in one benzene ring and two protons in another ring showed ortho coupling to each other, based on their NOESY correlations and coupling constants; $\delta_{\mathrm{H}} 6.91$ (d, H-4, H-5, J=9.0 Hz), 7.77 (d, H-3, H-6, $J=8.5 \mathrm{~Hz}$ ), 9.76 (s, CHO) (Table 2). The chemical shifts of the quaternary aromatic carbons indicated that three of the carbons were hydroxylated $\left(\delta_{\mathrm{C}} 127.61,164.09\right)$ and one carbon was an aldehyde group $\left(\delta_{\mathrm{C}}\right.$ 191.44). The connectivities between protons and carbons in the HSQC and $\mathrm{HMBC}$ spectra indicated that the proton $\mathrm{H}-3$ was ${ }^{2} J$ coupled with $\mathrm{C}-4\left(\delta_{\mathrm{C}} 115.56\right)$ and ${ }^{3} J$ coupled with $\mathrm{C}-1\left(\delta_{\mathrm{C}} 164.09\right)$ and $\mathrm{C}-11\left(\delta_{\mathrm{C}} 191.44\right)$; the proton $\mathrm{H}-4$ showed ${ }^{3} J$ coupling with C-2 $\left(\delta_{\mathrm{C}} 128.73\right)$; the proton $\mathrm{H}-5$ showed ${ }^{3} J$ coupling with $\mathrm{C}-7\left(\delta_{\mathrm{C}} 127.61\right)$; the proton $\mathrm{H}-11$ showed ${ }^{2} J$ coupling with $\mathrm{C}-2\left(\delta_{\mathrm{C}} 128.73\right)$ and ${ }^{3} J$ correlation with $\mathrm{C}-3\left(\delta_{\mathrm{C}} 132.05\right)$. Conclusively, we identified 10 as a new compound, 1,7,8-trihydroxy-2-naphtaldehyde. Naphthalene derivatives have previously been isolated from other plants such as from the rhizome of Eleutherine americana ${ }^{31}$ and roots of Diospyros assimilis. ${ }^{32}$

The phenolic compounds in the $80 \%$ ethanol extract of P. amarus, ie, GA, EA, Cor, and Ger, were identified and quantified by a validated reversed-phase HPLC method as previously reported by Jantan et al. ${ }^{21}$
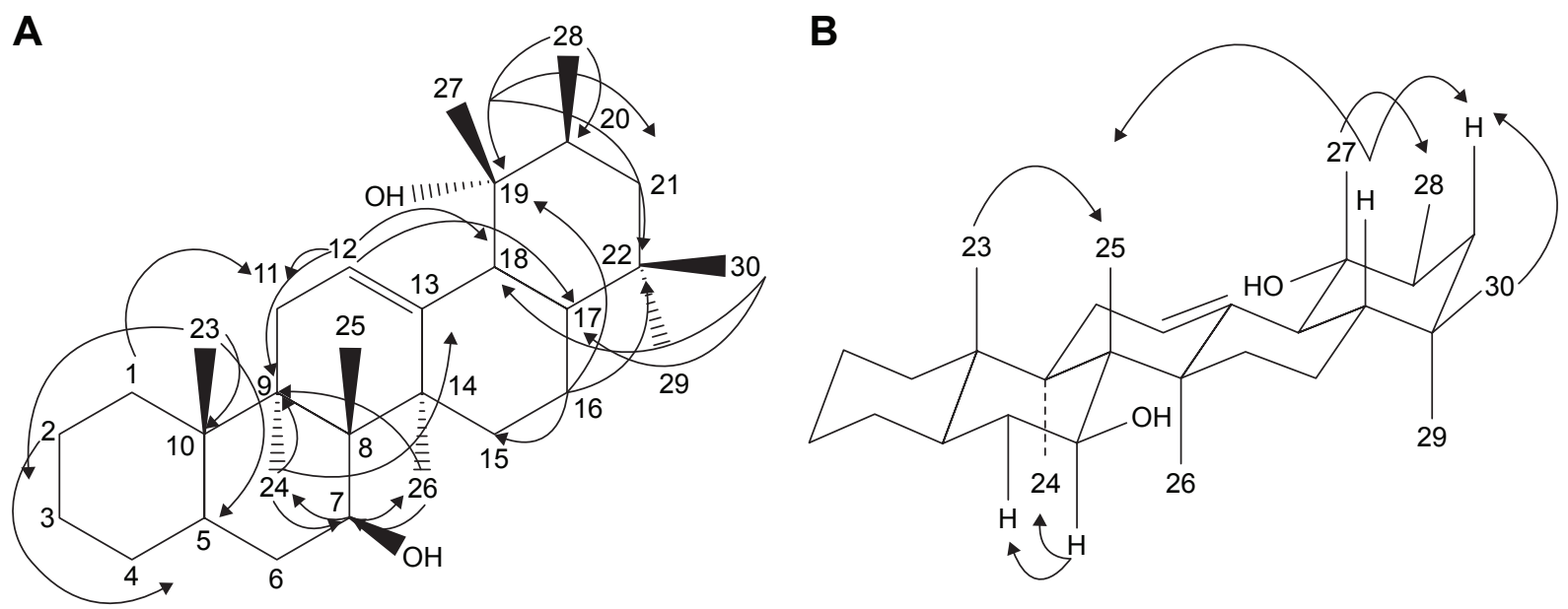

Figure 2 HMBC (A) and NOESY (B) correlation of $7 \beta, 19 \alpha$ dihydroxy-urs-12-ene (6). Abbreviations: HMBC, heteronuclear multiple bond correlation; NOESY, nuclear Overhauser effect spectroscopy. 
Table $3 I_{50}$ values $(\mu \mathrm{g} / \mathrm{mL})$ of lymphocyte proliferation, cytokine release, and $\mathrm{NO}$ inhibitory activities of $P$. amarus extract and its chemical constituents on phagocytes (mean \pm SEM, $n=3$ )

\begin{tabular}{|c|c|c|c|c|}
\hline Samples & $\begin{array}{l}\text { Lymphocyte } \\
\text { proliferation }\end{array}$ & Nitric oxide & TNF- $\alpha$ & IL-I $\beta$ \\
\hline P. amarus extract & $0.52 \pm 1.05$ & $4.84 \pm 3.14$ & $12.09 \pm 3.06$ & $7.58 \pm 3.21$ \\
\hline Ethyl 8-hydroxy-8-methyl-tridecanoate (I) & $3.78 \pm 1.43(13.93 \pm 3.77)$ & $0.25 \pm 0.01(0.91 \pm 0.03)$ & - & - \\
\hline Isolintetralin ${ }^{a}(2)$ & - & - & - & - \\
\hline I-triacontanol (3) & $2.36 \pm 0.20(5.39 \pm 0.46)$ & $1.01 \pm 0.28(2.30 \pm 0.68)$ & - & - \\
\hline Stigmasterol $^{a}(\mathbf{4})$ & - & - & - & - \\
\hline$\beta$-sitosterol ${ }^{\mathrm{a}}(\mathbf{5})$ & - & - & - & - \\
\hline $7 \beta, 19 \alpha$ dihydroxy-urs-12-ene ${ }^{a}(6)$ & - & - & - & - \\
\hline Hypophyllanthin (7) & $0.93 \pm 0.38(2.18 \pm 0.89)$ & $1.36 \pm 0.01(3.16 \pm 0.02)$ & $12.75 \pm 3.45(29.65 \pm 8.03)$ & - \\
\hline Phyltetralin (8) & $0.44 \pm 0.03(1.07 \pm 0.07)$ & $1.23 \pm 0.38(2.95 \pm 0.93)$ & - & - \\
\hline Phyllanthin (9) & $0.76 \pm 0.13(1.82 \pm 0.33)$ & $2.49 \pm 0.81(5.95 \pm 1.94)$ & $17.00 \pm 5.47(40.67 \pm 0.66)$ & - \\
\hline I,7,8-trihydroxy-2-naphtaldehyde (I0) & $5.84 \pm 0.89(28.67 \pm 4.37)$ & $0.22 \pm 0.10(1.07 \pm 0.31)$ & - & - \\
\hline GA & $0.96 \pm 0.69(5.66 \pm 4.05)$ & $4.12 \pm 0.80(24.17 \pm 2.50)$ & $13.92 \pm 4.65(76.32 \pm 7.12)$ & $35.28 \pm 3.62(194.99 \pm 6.35)$ \\
\hline EA & $\mid 3.23 \pm 1.24(43.77 \pm \mid .54)$ & $5.54 \pm 0.22(|8.36 \pm| .09)$ & $32.47 \pm 3.66(105.95 \pm 6.65)$ & $39.20 \pm 3.61(134.10 \pm 5.02)$ \\
\hline Ger & $\mid 2.31 \pm 1.68(22.60 \pm 1.32)$ & $4.25 \pm 0.47(7.8 I \pm 0.3 I)$ & $7.5 I \pm 5.3 I(8.66 \pm 2.5 I)$ & $14.80 \pm 2.56(|6.4| \pm 0.74)$ \\
\hline Cor & $11.08 \pm 1.17(17.4 \mathrm{I} \pm 2.12)$ & $5.07 \pm 1.75(7.98 \pm 2.05)$ & $4.60 \pm 2.99(7.39 \pm 2.53)$ & $27.40 \pm 1.17(43.19 \pm 2.53)$ \\
\hline Predni & $0.038 \pm 0.002(0.09 \pm 0.06)$ & - & - & - \\
\hline Dexa & - & $0.14 \pm 0.76(0.35 \pm 0.23)$ & $0.77 \pm 0.27(1.96 \pm 0.44)$ & $0.26 \pm 1.02(0.67 \pm 1.32)$ \\
\hline
\end{tabular}

Notes: $I C_{50}$ values $(\mu M)$ are in parentheses. ${ }^{a}$ Not determined. - indicates data not applicable.

Abbreviations: Cor, corilagin; Dexa, dexamethasone; EA, ellagic acid; GA, gallic acid; Ger, geraniin; IC ${ }_{50}$, half maximal inhibitory concentration; IL-I $\beta$, interleukin-I $\beta$; NO, nitric oxide; P. amarus, Phyllanthus amarus; Predni, prednisolone; SEM, standard error of the mean; TNF- $\alpha$, tumor necrosis factor- $\alpha$.

$P$. amarus extract was shown to possess inhibitory effects on phagocytic activity of human neutrophils in our previous study. ${ }^{20,21}$ In this study, ten compounds were isolated from $P$. amarus, but only six compounds were investigated for their immunomodulatory activity due to very limited amounts of compounds isolated ( 2 and $\mathbf{6}$ ) and also one sample was a mixture of stigmasterol (4) and $\beta$-sitosterol (5). The reference standards, GA, EA, Cor, and Ger were also investigated for their immunomodulatory activity. The cell viability test was performed using MTT assay to determine the nontoxic concentrations for PBMCs and RAW 264.7 cells. Only the viable and metabolically active cells can cleave the MTT to produce formazan, hence the more the color intensity of the medium the more the cells were viable. ${ }^{33,34}$ PBMCs were viable $(>90 \%)$ at $3.125 \mu \mathrm{g} / \mathrm{mL}$ and $100 \mu \mathrm{g} / \mathrm{mL}$ of the compounds after 4-day incubation, while at similar concentrations RAW 264.7 cells were also $>90 \%$ viable after 2-day incubation.

In agreement with the reactive oxygen species production activity as previously reported by us, ${ }^{20,21}$ most of the compounds tested exhibited strong inhibition on NO production, as compared with LPS-stimulated macrophages (Table 3, Figure 3). Both inhibition of NO and superoxide production consequently inhibited peroxynitrite formation, a highly reactive compound with various harmful effects on cells. ${ }^{35}$ Cells were pretreated with the different concentrations of compounds $(3.125-100 \mu \mathrm{g} / \mathrm{mL})$ before activation with LPS to activate inducible nitric oxide synthase (iNOS) synthesis

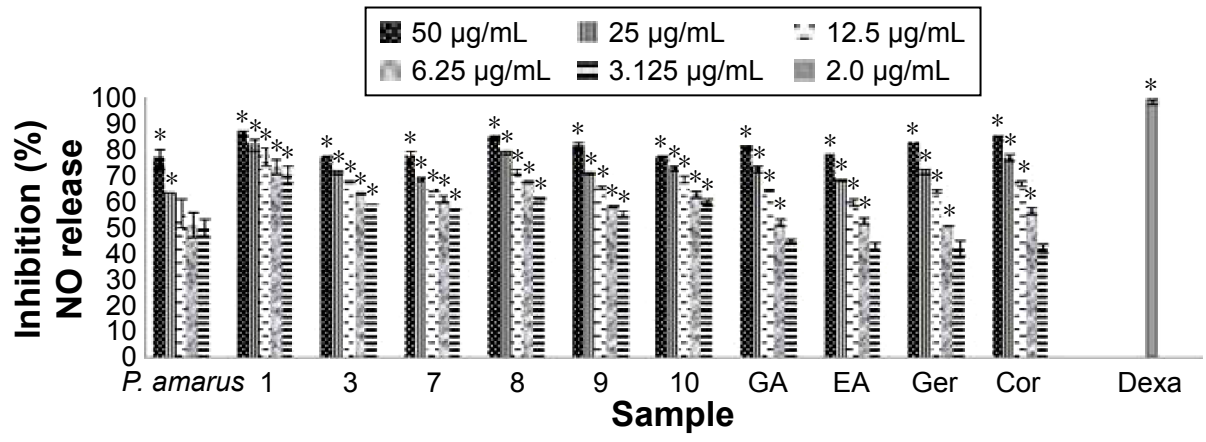

Figure 3 Percentage inhibition of NO release by P. amarus and its major compounds on LPS-stimulated RAW 264.7 cells.

Notes: Data are mean \pm SEM $(n=3)$. Significance of differences with respective control: $* P<0.05$. For Dexa, only percentage inhibition at $4 \mu$ g $/ m L$ is shown.

Abbreviations: Cor, corilagin; Dexa, dexamethasone; EA, ellagic acid; GA, gallic acid; Ger, geraniin; LPS, lipopolysaccharide; NO, nitric oxide; P. amarus, Phyllanthus amarus; SEM, standard error of the mean. 


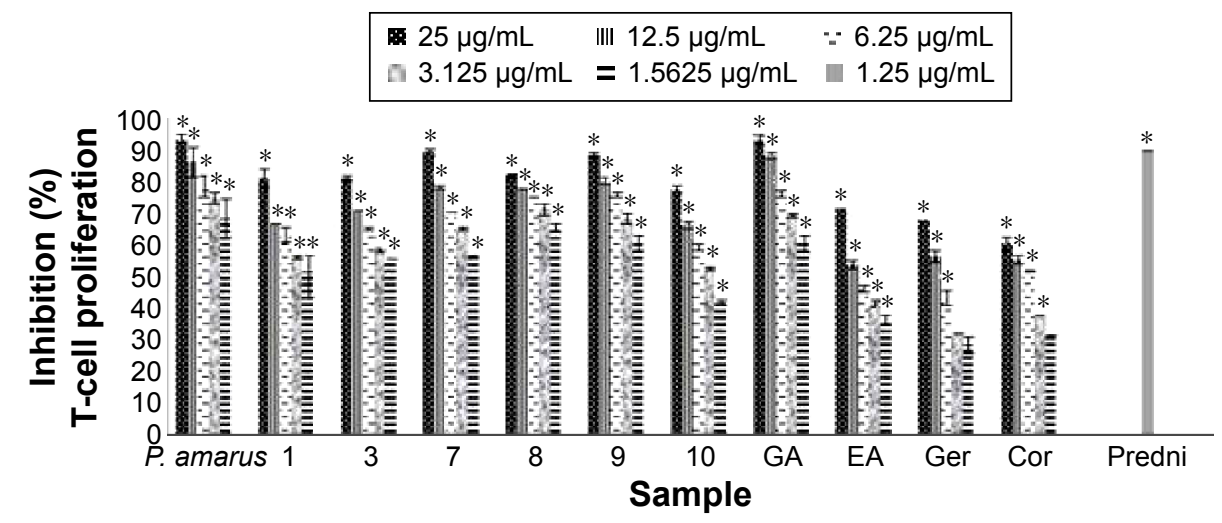

Figure 4 Percentage inhibition of T-cell proliferation by $P$. amarus and its major compounds on PHA-stimulated human PBMCs.

Notes: Data are mean \pm SEM $(n=3)$. Significance of differences with respective control: $* P<0.05$. For Predni, only percentage inhibition at $5 \mu g / m L$ is shown.

Abbreviations: Cor, corilagin; Dexa, dexamethasone; EA, ellagic acid; GA, gallic acid; Ger, geraniin; P. amarus, Phyllanthus amarus; PBMCs, peripheral blood mononuclear cells; PHA, phytohemagglutinin; Predni, prednisolone; SEM, standard error of the mean.

and eventually NO release. Among the compounds, ethyl 8-hydroxy-8-methyl-tridecanoate (1) and 1,7,8-trihydroxy2-naphtaldehyde (10) showed strong inhibitory activity on NO production by macrophages with $\mathrm{IC}_{50}$ values of $0.91 \mu \mathrm{M}$ and $1.07 \mu \mathrm{M}$, respectively, which were higher than dexamethasone $(0.35 \mu \mathrm{M}$; Table 3$)$. Dexamethasone was reported to have inhibitory activities on iNOS expression and NO production by destabilizing mRNA in LPS-treated macrophages. ${ }^{36}$

Lymphocytes can be activated to proliferate in vitro by mitogens such as PHA. The addition of compounds from $P$. amarus at the initiation of lymphocyte cultures inhibited proliferative responses (Table 3, Figure 4). Inhibition by the compounds could have resulted from a failure to initiate lymphocyte transformation or interference with the exponential increase in the number of dividing cells. ${ }^{37}$ All compounds significantly decreased the $\left[{ }^{3} \mathrm{H}\right]$ thymidine incorporation of proliferating (PHA-stimulated) lymphocytes in a dose-dependent manner, when compared to prednisolone, the positive control (Figure 4). Of all compounds, the lignans especially phyltetralin (8) exhibited the strongest inhibition on lymphocyte proliferation with an $\mathrm{IC}_{50}$ value of $1.07 \mu \mathrm{M}$, which was about ten times higher than prednisolone $(0.09 \mu \mathrm{M})$. Prednisolone was reported to have inhibitory activity on whole blood lymphocyte proliferation. ${ }^{38}$

The MAPK cascade regulates both NF- $\kappa$ B- and AP1 -associated gene transcription. The activation of this system by extracellular stimuli such as the bacterial product LPS resulted in increasing levels of the inflammatory enzymes cyclooxygenase-2 (COX-2) and of cytokines. ${ }^{38}$ Cor and Ger exhibited moderate inhibitory activity on TNF- $\alpha$ from PBMCs with $\mathrm{IC}_{50}$ values of $7.39 \mu \mathrm{M}$ and $8.66 \mu \mathrm{M}$, respectively, whereas Ger depicted the strongest inhibitory activity on IL-1 $\beta$ release from PBMCs with an $\mathrm{IC}_{50}$ value of $16.41 \mu \mathrm{M}$ (Table 3, Figures 5 and 6). These compounds selectively inhibited TNF- $\alpha$ release. The results suggest that these compounds reduced the translocation of NF- $\kappa$ B induced by LPS and subsequently decreased the level of proinflammatory cytokines, especially TNF- $\alpha$ production. Blockage of TNF- $\alpha$ receptor is another possible mechanism. The inhibitory effects of Cor

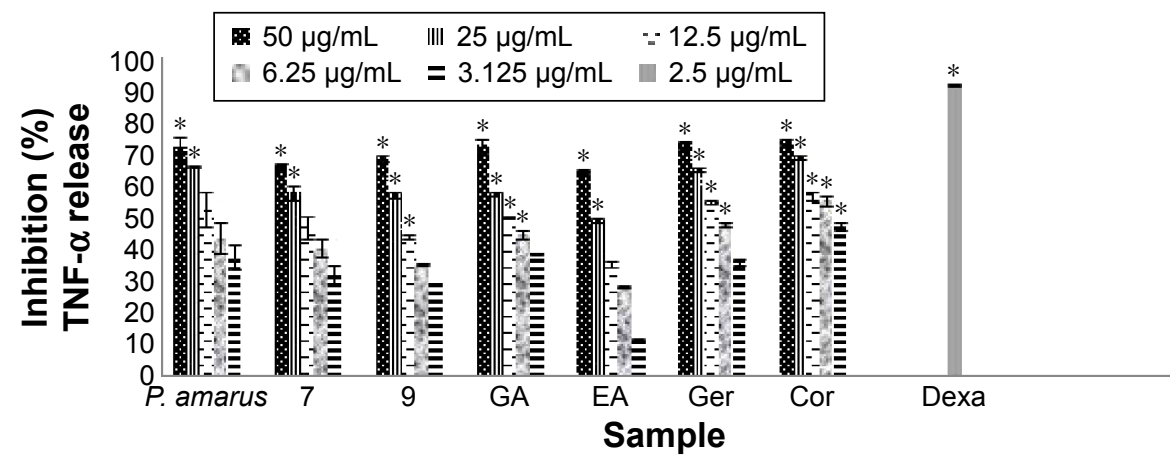

Figure 5 Percentage inhibition of TNF- $\alpha$ by $P$. amarus and its major compounds on LPS-stimulated human PBMCs.

Notes: Data are mean $\pm S E M(n=3)$. Significance of differences with respective control: $* P<0.05$. For Dexa, only percentage inhibition at $5 \mu g / m L$ is shown.

Abbreviations: Cor, corilagin; Dexa, dexamethasone; EA, ellagic acid; GA, gallic acid; Ger, geraniin; LPS, lipopolysaccharide; P. amarus, Phyllanthus amarus; PBMCs, peripheral blood mononuclear cells; SEM, standard error of the mean; TNF- $\alpha$, tumor necrosis factor- $\alpha$. 


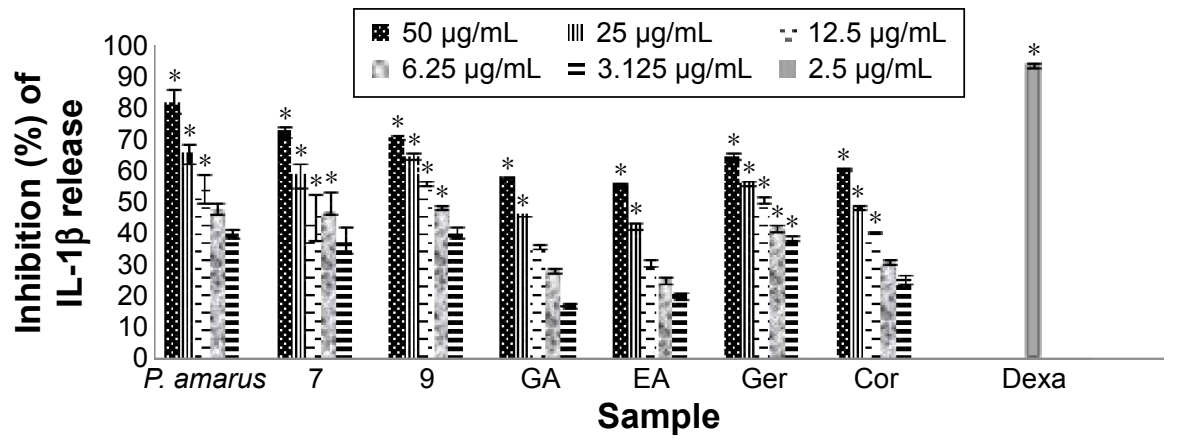

Figure 6 Percentage inhibition of IL-I $\beta$ by P. amarus and its major compounds on LPS-stimulated human PBMCs.

Notes: Data are mean $\pm \operatorname{SEM}(\mathrm{n}=3)$. Significance of differences with respective control: $* P<0.05$. For Dexa, only percentage inhibition at $5 \mu \mathrm{g} / \mathrm{mL}$ is shown.

Abbreviations: Cor, corilagin; Dexa, dexamethasone; EA, ellagic acid; GA, gallic acid; Ger, geraniin; IL-I $\beta$, interleukin-I $\beta$; LPS, lipopolysaccharide; P. amarus, Phyllanthus amarus; PBMCs, peripheral blood mononuclear cells; SEM, standard error of the mean.

and Ger on the innate immune response of phagocytes are comparable with previous studies. Cor has been reported to significantly reduce production of proinflammatory cytokines and mediators TNF- $\alpha$, IL-1 $\beta$, IL-6, NO (iNOS), and COX-2 on both protein and gene level by blocking NF-אB nuclear translocation in RAW 264.7 cell line. ${ }^{39}$ Cor has also been shown to be able to inhibit the double-strand break-triggered NF- $\kappa \mathrm{B}$ pathway in irradiated microglial cells. ${ }^{40}$ Ger and other polyphenols have been shown to suppress LPS-induced NF- $\kappa B$ activity through downregulation of IKB kinase activity in macrophages..$^{41}$ Our previous study has demonstrated that Ger, Cor, and EA had lower $\mathrm{IC}_{50}$ values than that of ibuprofen in blocking the migration of polymorphonuclear leukocytes. ${ }^{21}$

\section{Conclusion}

Among the compounds tested, the lignans, especially phyltetralin (8) and phyllanthin (9), showed strong inhibition on lymphocyte proliferation, while ethyl 8-hydroxy-8-methyltridecanoate (1) and 1,7,8-trihydroxy-2-naphtaldehyde (10) exhibited strong inhibition on NO production. Cor was the strongest inhibitor of TNF- $\alpha$ release, whereas Ger depicted the strongest inhibitory activity on IL- $1 \beta$ release. The compounds constituting the extract of $P$. amarus were able to inhibit the innate immune response of phagocytes at different steps.

The results suggest that the strong immunosuppressive effect of the plant extract was mainly contributed by these compounds, which could be further developed into leads for the development of immune-related disorders including inflammation.

\section{Acknowledgment}

The work was supported by the Ministry of Agriculture and Agro-Based Industry, Malaysia, under the NKEA Research Grant Scheme (Grant no NH1014D020).

\section{Disclosure}

The authors report no conflicts of interest in this work.

\section{References}

1. Kolaczkowska E, Kubes P. Neutrophil recruitment and function in health and inflammation. Nat Rev Immunol. 2013;13(3):159-175.

2. Mosmann TR, Cherwinski H, Bond MW, Giedlin MA, Coffman RL. Two types of murine helper T cell clone. I. Definition according to profiles of lymphokine activities and secreted proteins. J Immunol. 1986;136(7): 2348-2357.

3. Turvey S, Broide DH. Innate immunity. J Allergy Clin Immunol. 2010; 125(2 suppl 2):24.

4. van der Nat JM, Klerx JP, van Dijk H, de Silva KT, Labadie RP. Immunomodulatory activity of an aqueous extract of Azadirachta indica stem bark. J Ethnopharmacol. 1987;19(2):125-130.

5. Gautam M, Diwanay S, Gairola S, Shinde Y, Patki P, Patwardhan B. Immunoadjuvant potential of Asparagus racemosus aqueous extract in experimental system. J Ethnopharmacol. 2004;91(2-3):251-255.

6. Jayathirtha MG, Mishra SH. Preliminary immunomodulatory activities of methanol extracts of Eclipta alba and Centella asiatica. Phytomedicine. 2004;11(4):361-365.

7. Yu L, Zhao M, Yang B, Bai W. Immunomodulatory and anti-cancer activities of phenolics from Garcinia mangostana fruit pericarp. Food Chem. 2009;116(4):969-973.

8. Liu Z, Mouming Z, Kegang W, Xianghua C, Hongpeng Y. Immunomodulatory and anti-cancer activities of phenolics from emblica fruit (Phyllanthus emblica L.). Food Chem. 2012;131(2):685-690.

9. Calixto JB, Santos ARS, Filho VC, Yunes RA. A review of the plants of the genus Phyllanthus: their chemistry, pharmacology and therapeutic potential. Med Res Rev. 1998;18(4):225-258.

10. Foo LY, Wong H. Phyllanthusiin D, an unusual hydrolysable tannin from Phyllanthus amarus. Phytochemistry. 1992;31(2):711-713.

11. Foo LY. Amariin, a di-dehydro hexahydroxy diphenoyl hydrolysable tannin from Phyllanthus amarus. Phytochemistry. 1993;33:487-491.

12. Foo LY. Amarinic acid and related ellagitannins from Phyllanthus amarus. Phytochemistry. 1995;39:217-224.

13. Shokunbi OS, Odotela AA. Gastroprotective and antioxidant activities of Phyllanthus amarus extracts on absolute ethanol-induced ulcer in albino rats. J Med Plants Res. 2008;2(10):261-267.

14. Wang M, Cheng H, Li Y, Meng L, Zhao G, Mai K. Herbs of genus Phyllanthus in the treatment of chronic hepatitis B: observations with three preparations from different geographic sites. J Lab Clin Med. 1995; 126(4):350-352.

15. Kassuya CAL, Silvestre AA, Rehder VLG, Calixto JB. Anti-allodynic and anti-oedematogenic properties of the extract and lignans from Phyllanthus amarus in models of persistent inflammatory and neuropathic pain. Eur J Pharmacol. 2003;478(2-3):145-153. 
16. Kassuya CAL, Leite DF, de Melo LV, Rehder VL, Calixto JB. Antiinflammatory properties of extracts, fractions and lignans isolated from Phyllanthus amarus. Planta Med. 2005;71(8):721-726.

17. Adeneye AA, Amole OO, Adeneye AK. Hypoglycemic and hypocholesterolemic activities of the aqueous leaf and seed extracts of Phyllanthus amarus in mice. Fitoterapia. 2006;77(7-8):511-514.

18. Krithika R, Mohankumar R, Verma RJ, et al. Isolation, characterization and antioxidative effect of phyllanthin against $\mathrm{CCl}_{4}$-induced toxicity in HepG2 cell line. Chem Biol Interact. 2009;181(3):351-358.

19. Patel JR, Tripatnhi P, Sharma V, Chauhan NS, Dixi VK. Phyllanthus amarus: ethnomedical uses, phytochemistry and pharmacology: a review. J Ethnopharmacol. 2011;138(2):286-313.

20. Yuandani, Ilangkovan M, Jantan I, et al. Inhibitory effects of standardized extracts of Phyllanthus amarus and Phyllanthus urinaria and their marker compounds on phagocytic activity of human leukocyte. Evid Based Complement Alternat Med. 2013;2013:9. [Article ID 603634].

21. Jantan I, Ilangkovan M, Yuandani Mohamad HF. Correlation between the major components of Phyllanthus amarus and Phyllanthus urinaria and their inhibitory effects on phagocytic activity of human neutrophils. BMC Complement Altern Med. 2014;14:429.

22. Wang JX, Hou LF, Yang Y, Tang W, Li Y, Zuo JP. SM905, an artemisinin derivative, inhibited NO and pro-inflammatory cytokine production by suppressing MAPK and NF- $\kappa$ B pathways in RAW 264.7 macrophages. Acta Pharmacol Sin. 2009;30(10):1428-1435.

23. Gmelig-Meyling F, Waldmann TA. Separation of human blood monocytes and lymphocytes on a continuous percoll gradient. J Immunol Methods. 1980;33(1):1-9.

24. Yang EJ, Yim EY, Song G, Kim GO, Hyun CG. Inhibition of nitric oxide production in lipopolysaccharide-activated RAW 264.7 macrophages by Jeju plant extracts. Interdiscip Toxicol. 2009;2(4):245-249.

25. Amirghofran Z, Bakht MA, Karimi MH. Evaluation of the immunomodulatory effects of five herbal plants. J Ethnopharmacol. 2000;72(1-2): 167-172.

26. Kumolosasi E, Salim E, Jantan I, Ahmad W. Kinetics of intracellular, extracellular and production of pro-inflammatory cytokines in lipopolysaccharide-stimulated human peripheral blood mononuclear cells. Trop J Pharm Res. 2014;13(4):536-543.

27. Anjaneyulu ASR, Rao KJ, Row LR, Subrahmanyam C. Crystalline constituents of euphorbiaceae-XII, isolation and structural elucidation of three new lignans from the leaves of Phyllanthus niruri Linn. Tetrahedron. 1973;29(10):1291-1298.

28. Somanabandhu A, Nitayangkura N. ${ }^{1} \mathrm{H}$ and ${ }^{13} \mathrm{C}-\mathrm{NMR}$ assignments of phyllanthin and hypophyllanthin: lignan that enhance cytotoxic responses with cultured multidrug-resistant cells. J Nat Prod. 1993;56(2):233-239.
29. Kamboj A, Saluja AK. Isolation of stigmasterol and B-sitosterol from petroleum ether extract of aerial parts of Ageratum conyzoides (Asteraceae). Int J Pharm Pharm Sci. 2011;3(1):94-96.

30. Lu H, Wu X, Liang Y, Zhang J. Variation in chemical composition and antibacterial activities of essential oils from two species of Houttuynia Thunb. Chem Pharm Bull. 2006;54(7):936-940.

31. Zhengxiong $\mathrm{C}$, Huizhu $\mathrm{H}$, Chengrui W, et al. Hongconin, a new naphthalene derivative from Hong-Cong, the rhizome of Eleutherina americana Merr. Et Heyne (Iridaceae). Chem Pharm Bull. 1986;34(7): 2743-2746.

32. Ganapaty S, Steve Thomas P, Karagianis G, Waterman PG, Brun R. Antiprotozoal and cytotoxic naphthalene derivatives from Diospyros assimilis. Phytochemistry. 2006;67(17):1950-1956.

33. Mosmann T. Rapid colorimetric assay for cellular growth and survival: application to proliferation and cytotoxic assay. J Immunol Methods. 1983;65(1-2):55-63.

34. Kobayashi SD, Voyich JM, Burlak C, DeLeo FR. Neutrophils in the innate immune response. Arch Immunol Ther Exp (Warsz). 2005;53(6): 505-517.

35. Muijsers RBR, van den Worm F, Folkerts G, et al. Apocynin inhibits peroxynitrite formation by murine macrophages. Br J Pharmacol. 2000; 130(4):932-936

36. Korhonen R, Lahti A, Hämäläinen M, Kankaanranta H, Moilanen E. Dexamethasone inhibits inducible nitric-oxide synthase expression and nitric oxide production by destabilizing MRNA in lipopolysaccharidetreated macrophages. J Pharmacol Exp Ther. 2002;62(3):698-704.

37. Peavy DL, Koff WC, Hyman DS, Knight V. Inhibition of lymphocyte proliferative responses by ribavirin. Infect Immun. 1980;29(2): 583-589.

38. Magee MH, Blum RA, Lates CD, Jusko WJ. Pharmacokinetic/ pharmacodynamic model for prednisolone inhibition of whole blood lymphocyte proliferation. J Clin Pharmacol. 2002;53(5):474-484.

39. Zhao L, Zhang SL, Tao JY, et al. Preliminary exploration on anti-inflammatory mechanism of corilagin (beta-1-O-galloyl-3,6- $(R)$ hexahydroxydiphenoyl-D-glucose) in vitro. Int Immunopharmacol. 2008;8(7):1059-1064.

40. Dong XR, Luo M, Fan L, et al. Corilagin inhibits the double strand break-triggered NF-kB pathway in irradiated microglial cells. Int J Mol Med. 2010;25(4):531-536.

41. Pan MH, Lin-Shiau SY, Ho CT, Lin JH, Lin JK. Suppression of lipopolysaccharide-induced nuclear factor-kB activity by theaflavin3,3'-digallate from black tea and other polyphenols through downregulation of IkB kinase activity in macrophages. Biochem Pharmacol. 2000;59(4):357-367.

\section{Publish your work in this journal}

Drug Design, Development and Therapy is an international, peerreviewed open-access journal that spans the spectrum of drug design and development through to clinical applications. Clinical outcomes, patient safety, and programs for the development and effective, safe, and sustained use of medicines are a feature of the journal, which

\section{Dovepress}

has also been accepted for indexing on PubMed Central. The manuscript management system is completely online and includes a very quick and fair peer-review system, which is all easy to use. Visit http://www.dovepress.com/testimonials.php to read real quotes from published authors. 